\title{
VIKTÓRIA KIRÁLYNŐ KEZEIHEZ
}

Ezzel a figyelemfelhívó címmel kezdődik Frank Tibor történész-akadémikus legújabb könyve, amelyben közel öt évtizede tartó kutatásait foglalja össze - ezúttal elöször magyar nyelven - a 19. század második felének brit-magyar diplomáciai és politikai kapcsolatairól. A témához illően elegáns kivitelü, igényesen szerkesztett kötet címe a követi jelentések szokásos bevezető mondatára utal, amellyel a diplomaták a brit uralkodónak címezték beszámolóikat. Nem pusztán szellemes címadásról van azonban szó, hanem valós történészi forrásfeltáró munkáról, amelynek köszönhetően a szerző számos diplomáciai jelentést saját fordításában ad közre a brit külügyminisztérium levéltárából. A kötet függelékében közölt, 1866-ból származó feljegyzések részletes betekintést nyújtottak a szigetország kormányának a Magyarországon várható politikai fordulatról, arról a hosszadalmas tárgyalássorozatról, amely egy évvel később elvezetett a kiegyezés megkötéséig és az Osztrák-Magyar Monarchia megalakulásáig. Gyanítható, hogy ezen jelentések némelyike valóban eljutott Viktória királynő kezeihez. Az itt olvasható források jól kiegészítik a történészek által már korábban közzétett spanyol és francia beszámolókat az átalakuló Magyarország politikai életéről. Tovább bővül tehát tudásunk arról, hogy milyen is volt régiónk nemzetközi megítélése, és ismét rácsodálkozhatunk arra, hogy mennyire részletes információkkal rendelkeztek a magyar belpolitika fejleményeiről az európai diplomáciai központokban. Mindazonáltal, a szerző is hangsúlyozza, hogy a jól tájékozottság nem eredményezett feltétlenül aktív szerepvállalást: Nagy-Britannia számos ok miatt a be nem avatkozás elvét vallotta Közép-Európával kapcsolatban, ugyanakkor a pozitív semlegesség jegyében sokáig a dualista Monarchia fennmaradását elengedhetetlennek tartotta a nagyhatalmi erőegyensúly megőrzése érdekében. A követi jelentések és a Magyarországról megjelenő angol újságcikkek azonban már a kiegyezés táján figyelmeztetnek a nemzetiségi konfliktusok veszélyeire.

Ugyancsak érdekes fejezetei Frank Tibor könyvének azok, amelyek részletekbe menően bemutatják a diplomácia munka korabeli világát, egyrészt Apponyi György gróf 1856 és 1871 közötti londoni követi tevékenysége, másrészt a bécsi brit követség müködése kapcsán. Az elemzés során felhasznált hivatali és magánlevelezésekből színes képet kaphatunk a diplomáciában oly fontos társasági eseményekről, a szövevényes sajtókapcsolatokról, az angliai magyar emigráció (például Kossuth Lajos, Pulszky Ferenc) elképzeléseiről, valamint azokról a propagandaakciókról, amelyeket a bécsi külügyminisztérium indított a szigetországi közvélemény befolyásolása érdekében. A londoni követség személyi összetételének és a diplomaták karrierútvonalának vizsgálata pedig hasznosan egészíti ki 
Somogyi Éva kutatásait, aki 2017-ben tette közzé monográfiáját a bécsi közös külügyminisztérium magyar tisztviselöiről.

A kötet az alcímében megjelölt időhatárokat kitágítva, széles merítésủ áttekintéssel szolgál azokról a brit újságcikkekről és útleírásokról, amelyek Magyarország és részben az Osztrák-Magyar Monarchia belső viszonyaival foglalkoztak, de a korban szokásos módon rendszerint kitértek a magyarok nemzeti karakterére is. Ezen írásmüvek különösen a porosz-osztrák háború időszakában (1866), valamint a kiegyezés sajátos közjogi konstrukciója kapcsán szaporodtak meg. Utóbbi azért is válhatott elemzések tárgyává a szigetországban, mert több szerző követendő példát látott abban, ahogy az osztrák és a magyar politikai elit félretéve évszázados ellentétét, megállapodott a Habsburgok birodalmának közös fenntartásában. Ahogy a magyar politikusok figyeltek az 1814-ben létrejött svéd-norvég unió múködésére, úgy kutatták az ír és angol politikusok, értelmiségiek is az 1867-es politikai rendezés lehetséges tanulságait. A hazai „,anglománia” mellett tehát esetenként a magyar (és az osztrákokkal közös) politikai rendszer is szolgálhatott figyelemre méltó modellként a brit politikai gondolkodás számára. Frank Tibor bőven idéz pró és kontra érveket: míg például John Stuart Mill 1867 őszén hosszú levélben vetette el, hogy létezne bármiféle hasonlóság a magyarok és az írek helyzete között, addig Gladstone miniszterelnök az 1880-as években és Arthur Griffith ír nacionalista politikus a századfordulón komolyan hivatkozott 1867 pozitív példájára a birodalmon belüli nemzeti önrendelkezés lehetőségeiröl folytatott vitákban. Persze, nem szabad elfelejtenünk, hogy ezeknek a vélt vagy valós hasonlóságoknak az értelmezése mindig térhez és időhöz kötött, éppen ezért igen sokféle lehetett. Ami a századforduló táján nagyfokú önállóságnak tünt Londonból vagy Dublinból, az csupán reális kompromisszum volt Budapestről, illetve a nemzet halálát jelentő önfeladás Torinóból nézve. Frank Tibor könyvének legnagyobb erénye éppen abban áll, hogy miközben sokszínüen bemutatja az angol-magyar politikai és gazdasági kapcsolatok felívelő korszakát, mindvégig hangsúlyozza a brit „képalkotás” mozaikos voltát és az ekkor kialakult „országimázs" törékenységét.

(Frank Tibor: Viktória királynő kezeihez. Az osztrák-magyar kiegyezés brit tükörben, 1865-1870. Budapest: Gondolat Kiadó, 2019, 352 o.)

Cieger András, PhD Bölcsészettudományi Kutatóközpont Történettudományi Intézete 